\title{
SELF-ASSESSMENT REPORTS FOR ACADEMIC PROGRESS: EVIDENCE FROM BUSINESS ADMINISTRATION FACULTIES OF HEIS IN AN EMERGING ECONOMY
}

\section{Sadia Shaikh $^{1^{*}}$, Mushtaque Ali Jariko ${ }^{2}$, Muhammad Faisal Sultan ${ }^{3}$, Muhammad Asif Qureshi ${ }^{4}$, Tania Memon} Mushtaque ${ }^{5}$

${ }^{1 *}$ Assistant Professor, Benazir School of Business, Benazir Bhutto Shaheed University, Karachi, Pakistan; ${ }^{2}$ Professor, IBA, University of Sindh, Jamshoro, Pakistan; ${ }^{3}$ Asssitant Professor, KASBIT, Karachi, Pakistan; ${ }^{4}$ Assistant Professor, Muhammad Ali Jinnah University, Karachi, Pakistan, ${ }^{5}$ Assistant Professor, IBA, University of Sindh, Jamshoro, Pakistan.

Email: ${ }^{1 *}$ sadiakhurram@live.com, ${ }^{2}$ mali.jariko@ usindh.edu.pk, ${ }^{3}$ mfaisal@kasbit.edu.pk, 4qureshimuhammadasif@gmail.com, ${ }^{5}$ taniamushtaque@usindh.edu.pk

Article History: Received on $17^{\text {th }}$ April 2021, Revised on $4^{\text {th }}$ May 2021, Published on $7^{\text {th }}$ May 2021

\section{Abstract}

Purpose of the study: Quality Enhancement Cells (QECs) are prudent and play a dynamic role in the advancement of quality in higher education. This study examined the role and significance of QEC's in HEIs in an emerging economy like Pakistan.

Methodology: This study is conducted on the perceived benefits of Self-Assessment Reports (SARs) to have an initial guideline for further investigation on the role of QECs. The research model for this study has been formulated from the outcomes of SARs devised in a previous similar study. The model was evaluated through quantitative analysis using SmartPLS, determining SARs benefits associated with academia and students.

Main Findings: The empirical findings indicated that faculty perception regarding SARs and their benefits are positive and the relationship between the assessed variables is significant.

Applications of this study: The study findings will benefit the policymakers in HEIs to induct SARs as an organizational development tool.

Novelty/Originality of this study: This research is novel in its nature as limited research work regarding SAR and QEC evaluation in Pakistan has hindered the research-related activities and strategic planning in this area.

Keywords: Higher Education Institutes (HEIs), Quality Enhancement Cells (QECs), Self-Assessment Reports (SARs), Emerging Economies, Academia, Education.

\section{INTRODUCTION}

Quality and quality management are much broader in the application that must not be confined only to industrial or manufacturing, particularly in today's world, where these concepts are unjustly confined to business studies (Vykydal, Folta \& Nenadal, 2020). This assertion is rational as technological advancement has proven to make these concepts integrated into all the other areas of life particularly to the higher education sector (Habib, Jamal, Khalil, \& Khan, 2020; Turi et al. 2019). The goal of the higher education sector is to make students competent enough so that they may reflect these qualities through their performance in professional practices (Sultan et al. 2019). Although in the higher education sector is better to assume quality management as the third-order model which takes input from educational, administrative, and social qualities (Vykydal et al., 2020), the assessment of education thus is also termed a systematic process (Aliyu et al., 2020), which uses qualitative as well as quantitative data to improve quality and capacity of teaching \& learning (Islam \& Chowdhury, 2015). However, formulation of Quality Enhancement Cells (QEC) in the higher education sector of Pakistan rooted in the formulation of (QAA) Quality Assurance Agency (Habib et al. 2021; Higher Education Commission of Pakistan a, n.d.), these departments are also supposed to work independently and also as the primary agent for attaining quality learning, especially in universities. However, the purpose of the Higher Education Commission (HEC) behind all this is to meet the international needs of higher education (Habib et al. 2021; Batool \& Qureshi, 2017). Thus, the department needs to assume several measures for quality optimization which also includes a mechanism for quality assessment of academic programs termed as self-assessment reports (Khan \& Ramzan, 2020; Higher Education Commission of Pakistan a, n. d.).

\section{Self-Assessment Reports}

Assessments apply to every discipline to education where the systematic process is conducted through qualitative \& quantitative data to evaluate the teaching, learning, and academic standards (Forsman et al., 2020; Islam \& Chowdhury, 2015). Numerous studies and articles have been published since 1990, which have investigated and focused on the various aspects or issues of quality in higher education, and various diverse opinions have been studied in this area until now (Vykydal et al., 2020). However, there is severe lacking research on quality and quality assurance perspectives concerning Pakistan (Khatoon \& Usmani, 2014; Usmani \& Khatoon, 2018). However, these studies are based on the performance of quality enhancement cells for degree programs and institutions. 
The Asian scenario of the Self-Assessment process indicates that faculty, students, staff, and employers do not stand on the same stance regarding quality in higher education (Islam \& Chowdhury, 2015; Vykydal et al., 2020). Thus, writing quantitative case studies on the performance of QEC departments as contended by Usmani and Khatoon (2018) is much difficult. Nevertheless, the outcome of the self-assessment process is SAR is significant (Higher Education Commission of Pakistan b, n.d.) \& it is mandatory to submit SARs for each program with a status of compliance (Usmani \& Khatoon, 2018). Initially, QEC had to face much resistance from management and faculty that were engaged in the implementation of quality assessment and evaluation practices (Usmani \& Khatoon, 2018). Therefore, it is better to conduct a quantitative study regarding the perceived benefits of SAR reports through faculty in order to device quantitative study which may aid and support previous assertions by Khatoon and Usmani (2014) and Usmani and Khatoon (2018).

\section{Significance and Scope}

This study is one of the premiers in highlighting the significance of SARs in detail and also provides evidence to conduct similar studies under different circumstances. The study also links theoretical \& conceptual frameworks available regarding the role of QEC to develop an applicable framework concerning business education in Pakistan. Thus, it is legitimate to indicate that the study is also not only a state of artwork but also a real pervasive issue for the education industry.

\section{Research Questions}

RQ.1: Do SARs produce a better impact on business education in Pakistan?

RQ.2: Do SARs provide a better understanding regarding the academic areas which need improvement?

RQ.3: Do SARs provide a better understanding of the significance of QEC in higher education institutes?

\section{LITERATURE REVIEW}

Quality Assurance Agency (QAA) is the base of quality enhancement in the higher education sector of Pakistan which aims to foster the level of education quality (Batool \& Qureshi, 2017). There are some parameters and initiatives of QAA which are similar all over the globe e.g., techniques for policy building and development of policy documents. Similar parameters apply to Pakistan where HEC uses QAA to formulate certain standards, tools, documents, and evaluation techniques for optimization of university-level teaching. However, the QEC of every entity is primarily responsible for the evaluation of various degree programs through a self-assessment approach (Khatoon \& Usmani, 2014). Additionally, Rahnuma (2021) and Islam and Chowdhury (2015) highlighted the purpose of self-assessment is not only to optimize the quality of teaching-learning but also for the quality enhancement of graduates. The assessments also have their benefits rooted in the governance of the institution and its departments. Moreover, self-assessment is also termed as the potent tool for self-efficacy and self-improvement (Schunk \& Ertmer, 1999) and also aid in the systematic review of progress and monitoring (Paris \& Paris, 2001). Apart from its benefits and advantages, previous literature has extensively pointed out the issues pertaining to self -assessment procedures such as Boud and Falchikov (2006), identified some significant possible variables in the self-assessment literature, and indicated the objectivity, consistency, and accuracy of the methodological approach of self-assessment studies. Similarly, the attributes of the participants are also widely considered including the participants' knowledge about the subject area, their expertise, and understanding of the self-assessment techniques (Evans, 2013; Boud, \& Falchikov, 1989). Relatedly, self-assessment training to faculty and students have been emphasized by researchers to increase the participant's interest in self-assessments and also to enhance their assessment skills (Sitzmann et al. 2010; Dunning, Heath, \& Suls, 2004; Stuart, Goldstein, \& Snope, 1980).

Self-assessment practices in organizations have been an attractive practice for a long and have been adopted by organizations, by and large, to ascertain the organizational work quality (Jose Tarí, 2010). Education institutes correspondingly use the same means to examine their organizational quality standing (McAdam, \& Welsh, 2000). Assessments lead to quality enhancement and provide means to sustain quality standards in organizations (Pratama, 2019), through the development of standards, inspecting, monitoring as well used to improve the standards in accordance with respondents' perspectives and opinions (Monteiro \& Nicolini, 2015; Hartley \& Downe, 2007). Thus, it is evidently asserted that self-assessments help managers in organizations and administrators in HEIs to improve their quality standards (Budiyanti, Patiro, Djajadi, \& Astuty, 2020), and also help in identifying organizational strengths and weak areas where improvement effort is to be implied (McAdam \& Welsh, 2000; Becket, \& Brookes, 2008).

The self-assessment benefits are also highlighted by Andrade and Valtcheva (2009) \& therefore it is optimal to believe that self-assessment provides tremendous aid not only to primary users like teachers \& students but also to the other concerned authorities (Uddin, 2016). However, in the scenario of Pakistan self-assessment is based on program evaluation (Raouf. 2006). The purpose of this type of evaluation is to measure the efficiency of the program through evaluating its contribution to vision, mission \& objectives. Moreover, program evaluation also provides structured guidelines to developers, runners, and users of the program to plan implement, and deliver the desired level of output. Thus, this study will provide the base to evaluate the extent to which the program is achieving the stated goals and objectives to enhance the standards of quality (Khatoon \& Usmani, 2014). 


\section{Theoretical Framework}

Studies like Islam and Chowdhury (2015) \& Uddin (2016) have analyzed self-assessment programs with the reference to higher education in Bangladesh. The study of Islam and Chowdhury (2015) was conducted in the scenario of business administration while the study of Uddin (2016) was conducted in social sciences scenario. Although both of the studies used datasets from all the stakeholders like faculty, students, this study is majorly associated with Islam and Chowdhury (2015) which also relate to the evaluation of standards with external peer review committee. The purpose of the committee is to evaluate the outcomes of Self-Assessment Reports (SARs) and provide recommendations for the betterment of stakeholders.

Moreover, it has also been indicated that the practice of using self-assessment reports was in its initial stages, especially in Bangladesh, therefore points used to evaluate self-assessment from students and faculty were reviewed by an external committee. In addition to this, SAR was pertaining specifically to business administration department universities. Thus, to review the process of self-assessment thoroughly, the initial data was collected from students, faculty, alumni, graduating students, and employers and the entire range of criterion used in the study is given below:

Table 1: Review Data on SARs

\begin{tabular}{llll}
\hline \multirow{2}{*}{ Sr. No. } & Benefits/ Criterions & \multicolumn{2}{c}{ Evaluated by } \\
\cline { 3 - 4 } & & Faculty & Students \\
\hline 01 & Governance & Yes & Yes \\
\hline 02 & Curriculum design and content review & Yes & Yes \\
\hline 03 & Teaching learning & Yes & Yes \\
\hline 04 & Learning Evaluation & Yes & Yes \\
\hline 05 & Institutional Facilities & Yes & Yes \\
\hline 06 & Institutional structure & Yes & Yes \\
\hline 07 & Recruitment promotion and development & Yes & No \\
\hline 08 & Institutional Support & Yes & No \\
\hline 09 & Student Support & Yes & Yes \\
\hline 10 & Student counseling & Yes & Yes \\
\hline 11 & Development of Skills & Yes & Yes \\
\hline 12 & Research and extension & Yes & Yes \\
\hline 13 & Process Control & Yes & Yes \\
\hline
\end{tabular}

Source: Adapted from Islam and Chowdhury (2015)

However, this study also includes parameters that resemble faculty satisfaction and student's satisfaction as indicated by Raouf (2006). Moreover, the parameters of Raouf (2006) are for the optimization of specific programs and these sorts of evaluations are the tool to verify the efficacy of the program (Khatoon \& Usmani, 2014). The standards mentioned in the manual formulated by Raouf (2006), are for writing SAR rather than for gauging the benefits of QEC or SAR. Therefore, the criterion used by Islam and Chowdhury (2015), to evaluate quality standards from students and faculty are selected in this study as the base of the research model (See Table 1). Though Table 1 was used to collect data even from different students e.g., current, passing, and alumni and faculty, which might not be the appropriate respondents to gauge the entire range of criterion individually. This study, therefore, prefers only those advantages which may reflect upon the betterment of academia and students (See Table 2). This has been done in consideration with Khatoon and Usmani (2014), which used only two initial standards of QEC manual for SAR writing and adapting for the betterment of quality. Therefore, the selected variables given in table 3 are chosen to analyze as tools to measure the benefits of SARs.

Table 2: Measures for SAR benefits

\begin{tabular}{ll}
\hline Sr. No. & Benefits/ Criterions \\
\hline 01 & Curriculum design and content review \\
\hline 02 & Teaching-learning \\
\hline 03 & Learning Evaluation \\
\hline 04 & Student Support \\
\hline 05 & Student counseling \\
\hline 06 & Development of Skills \\
\hline 07 & Research and extension \\
\hline
\end{tabular}

Source: Adapted from Khatoon and Usmani (2014)

Thus, from the literature validation above, the following research hypotheses are formulated:

$\mathbf{H}_{\mathbf{1}}$ : There is a positive impact of SAR writing on curriculum design and content review in business education.

$\mathbf{H}_{2}$ : There is a positive impact of SAR writing on the development of skills in students of business education. 
$\mathbf{H}_{3}$ : There is a positive impact of SAR writing on learning evaluation in business education.

$\mathbf{H}_{4}$ : There is a positive impact of SAR writing on research and extension in business education.

$\mathbf{H}_{5}$ : There is a positive impact of SAR writing on student counselling in business education.

$\mathbf{H}_{\mathbf{6}}$ : There is a positive impact of SAR writing on student support in business education.

$\mathbf{H}_{7}$ : There is a positive impact of SAR writing on teaching and learning in business education.

$\mathbf{H}_{\mathbf{8}}$ : Degree program does moderate the relationship of SAR writing with curriculum design and content review in business education.

$\mathbf{H}_{\mathbf{9}}$ : Degree program does moderate the relationship of SAR writing with the development of skills in students of business education.

$\mathbf{H}_{10}$ : Degree program does moderate the relationship of SAR writing with learning evaluation in business education.

$\mathbf{H}_{11}$ : Degree program does moderate the relationship of SAR writing with research and extension in business education.

$\mathbf{H}_{12}$ : Degree program does moderate the relationship of SAR writing with student counselling in business education.

$\mathbf{H}_{13}$ : The degree program does moderate the relationship of SAR writing with student support in business education.

$\mathbf{H}_{14}$ : Degree program does moderate the relationship of SAR writing on teaching and learning in business education.

\section{METHODOLOGY}

\section{Research Design}

This study has adopted research design from other previous research studies of Batool and Qureshi (2017); Islam and Chowdhury (2015); Khatoon and Usmani (2014) and Raouf (2006). The philosophical stance of the research epistemological as the study is for knowledge optimization concerning quality enhancement in the higher education sector. The linkage of study with epistemology is appropriate enough as epistemology is associated with knowledge, creation of knowledge, and devising good knowledge (Bawden, 2007). The technique used in the study is quantitative and the technique of data collection and analysis is based on major research questions and paradigms pertaining to the study. The research strategy is espoused in the survey technique as the research is based on primary data from HEI's faculty. However, the conditions prevailing due to COVID-19 the respondents were allowed to fill questionnaire at their convenience. The data for the study was collected from December 2020 to March 2021.

\section{Sampling Design}

According to the pattern indicated by Islam and Chowdhury (2015) and Roauf (2006), faculty is always the best for collecting the data for self-assessment program. However, the program must be evaluated separately i.e., with respect to years of schooling \& title of the program (Roauf, 2006; Usmani \& Khatoon, 2018). Thus, this study uses only those faculty members who are experienced in making SAR for Bachelor of Business Administration. Moreover, the criteria for self-assessment are implemented in Pakistan for fourteen years (Raouf, 2006) therefore this is not a new form of evaluation as it was in Shah Jalal University in Bangladesh (Islam \& Chowdhury, 2015). Hence this study uses experienced faculty members who also hold experience of working as the program teams for self-assessment reports. However, the study is one of the foremost studies on the subject area therefore initially it works only for the Bachelor of Business Administration program as done by Islam and Chowdhury (2015). Therefore, following this criterion makes the study based on a smaller size, and to make it effective enough the study includes the opinion of experienced program team members from higher educational institutes of Karachi, Pakistan. Considering Karachi as the population of the study is that the Karachi has the highest number of HEC recognized campuses for the different public sector and private sector universities (Higher Education Commission of Pakistan b, n. d.).

Questionnaire: The questionnaire has been developed by considering the elements and points mentioned by Islam and Chowdhury (2015) and Khatoon and Usmani (2014). Questionnaires were also transformed into a Likert scale to gauge attitudes (Likert, 1932) of faculty regarding the importance and significance of writing SARs. Moreover, the use of the Likert scale helps relate the study to different dimensions (Revilla, Saris \& Krosnick, 2014) to optimize implication through masses (Johns, 2005; Johns, 2010).

Software and Statistical Testing: There are few studies in the context of Pakistan which are aligned with quality optimization and QEC e.g., Khatoon and Usmani (2014) and Usmani and Khatoon (2018). Although almost none of these indicated the significance and use of SAR reports in the quality optimization of degree programs. Therefore, criterions considered are from a study from Bangladesh i.e., Islam and Chowdhury (2015) to gauge the significance of writing SARs concerning faculty members. Thus, this study must be inclined with the theory-building approach. Thus, it is valid to incorporate SMART-PLS software, due to its ability to deal with relevant conditions and reputation in the field of statistical testing (Benitez, Henseler, Castillo \& Schuberth, 2020). The software is the best solution for 
descriptive analysis and inferential modelling (Richter, Sinkovics, Ringle \& Schlaegel, 2016). This study measurement model is reflective \& therefore must be analyzed as per the indication of Afthanorhan (2014) and Hair et al. (2019).

\section{RESULTS AND ANALYSIS}

Table $3 \& 4$ indicate the outer loadings of the model and according to Afthanorhan (2014), 0.60 is the least acceptable value for any element which is required to be included in the model. However, inclusion becomes more effective with the values getting closer to 1 (Khan, Sarstedt, Shiau, Hair, Ringle \& Fritze, 2019). Though according to the table none of the elements used in the questionnaire is producing outer loading lesser than 0.708 . Therefore, it is justified to consider the criterion effective for analysis (Hair, Sarstedt, Ringle \& Mena, 2011).

Table 3: Outer Loadings

\begin{tabular}{|c|c|c|c|c|c|c|c|c|c|c|}
\hline & $\begin{array}{l}\text { Curr. } \\
\text { Des. } \\
\text { Cont. } \\
\text { Rev. }\end{array}$ & \& & $\begin{array}{l}\text { Degree } \\
\text { Prog. }\end{array}$ & $\begin{array}{l}\text { Dev. of } \\
\text { Skills }\end{array}$ & $\begin{array}{l}\text { Learn. } \\
\text { Eval. }\end{array}$ & $\begin{array}{l}\text { Res. \& } \\
\text { Ext. }\end{array}$ & $\begin{array}{l}\text { Stud. } \\
\text { Coun. }\end{array}$ & $\begin{array}{l}\text { Stud. } \\
\text { Supp. }\end{array}$ & $\begin{array}{l}\text { Teach. } \\
\& \\
\text { Learn. }\end{array}$ & $\begin{array}{l}\text { Writing } \\
\text { SARs }\end{array}$ \\
\hline CD1 & 0.830 & & & & & & & & & \\
\hline CD2 & 0.846 & & & & & & & & & \\
\hline CD3 & 0.842 & & & & & & & & & \\
\hline CD4 & 0.848 & & & & & & & & & \\
\hline DP & & & 1.000 & & & & & & & \\
\hline DS1 & & & & 0.752 & & & & & & \\
\hline DS2 & & & & 0.892 & & & & & & \\
\hline DS3 & & & & 0.836 & & & & & & \\
\hline LE1 & & & & & 0.908 & & & & & \\
\hline LE2 & & & & & 0.792 & & & & & \\
\hline LE3 & & & & & 0.885 & & & & & \\
\hline RE1 & & & & & & 0.844 & & & & \\
\hline RE2 & & & & & & 0.914 & & & & \\
\hline RE3 & & & & & & 0.892 & & & & \\
\hline SC1 & & & & & & & 0.884 & & & \\
\hline SC2 & & & & & & & 0.874 & & & \\
\hline SC3 & & & & & & & 0.944 & & & \\
\hline SS1 & & & & & & & & 0.778 & & \\
\hline
\end{tabular}

Source: Study Analysis

Table 4: Outer Loadings

\begin{tabular}{|c|c|c|c|c|c|c|c|c|c|c|c|c|c|c|c|c|}
\hline & $\begin{array}{l}\text { Curr. } \\
\text { Des. \& } \\
\text { Cont. } \\
\text { Rev. }\end{array}$ & $\begin{array}{l}\text { Deg } \\
\text { ree } \\
\text { Pro } \\
\text { g. }\end{array}$ & $\begin{array}{l}\text { Dev } \\
\text {.of } \\
\text { Skil } \\
\text { ls }\end{array}$ & $\begin{array}{l}\text { Lea } \\
\text { rn. } \\
\text { Eva } \\
\text { l. }\end{array}$ & $\begin{array}{l}\text { Mo } \\
\text { d } \\
\text { Eff } \\
1\end{array}$ & $\begin{array}{l}\text { Mo } \\
\text { d } \\
\text { Eff } \\
2 \\
\end{array}$ & $\begin{array}{l}\text { Mo } \\
\text { d } \\
\text { Eff } \\
3\end{array}$ & $\begin{array}{l}\text { Mo } \\
\text { d } \\
\text { Eff } \\
4 \\
\end{array}$ & $\begin{array}{l}\text { Mo } \\
\text { d } \\
\text { Eff } \\
5\end{array}$ & $\begin{array}{l}\text { Mo } \\
\text { d } \\
\text { Eff } \\
6\end{array}$ & $\begin{array}{l}\text { M } \\
\text { od } \\
\text { Eff } \\
7\end{array}$ & $\begin{array}{l}\text { Res } \\
. \quad \& \\
\text { Ext } \\
.\end{array}$ & $\begin{array}{l}\text { Stu } \\
\text { d. } \\
\text { Co } \\
\text { un. }\end{array}$ & $\begin{array}{l}\text { Stu } \\
\text { d. } \\
\text { Sup } \\
\text { p. }\end{array}$ & $\begin{array}{l}\text { Teac } \\
\text { h. \& } \\
\text { Lear } \\
\text { n. }\end{array}$ & $\begin{array}{l}\text { Wri } \\
\text { ting } \\
\text { SAR } \\
\text { S }\end{array}$ \\
\hline SS2 & & & & & & & & & & & & & & $\begin{array}{l}\text { 0.8 } \\
77 \\
\end{array}$ & & \\
\hline SS3 & & & & & & & & & & & & & & $\begin{array}{l}0.8 \\
68\end{array}$ & & \\
\hline TL1 & & & & & & & & & & & & & & & 0.878 & \\
\hline TL2 & & & & & & & & & & & & & & & 0.944 & \\
\hline TL3 & & & & & & & & & & & & & & & 0.886 & \\
\hline WR1 & & & & & & & & & & & & & & & & $\begin{array}{l}0.90 \\
4 \\
\end{array}$ \\
\hline WR2 & & & & & & & & & & & & & & & & $\begin{array}{l}0.92 \\
6 \\
\end{array}$ \\
\hline WR3 & & & & & & & & & & & & & & & & $\begin{array}{l}\mathbf{0 . 8 9} \\
7 \\
\end{array}$ \\
\hline
\end{tabular}




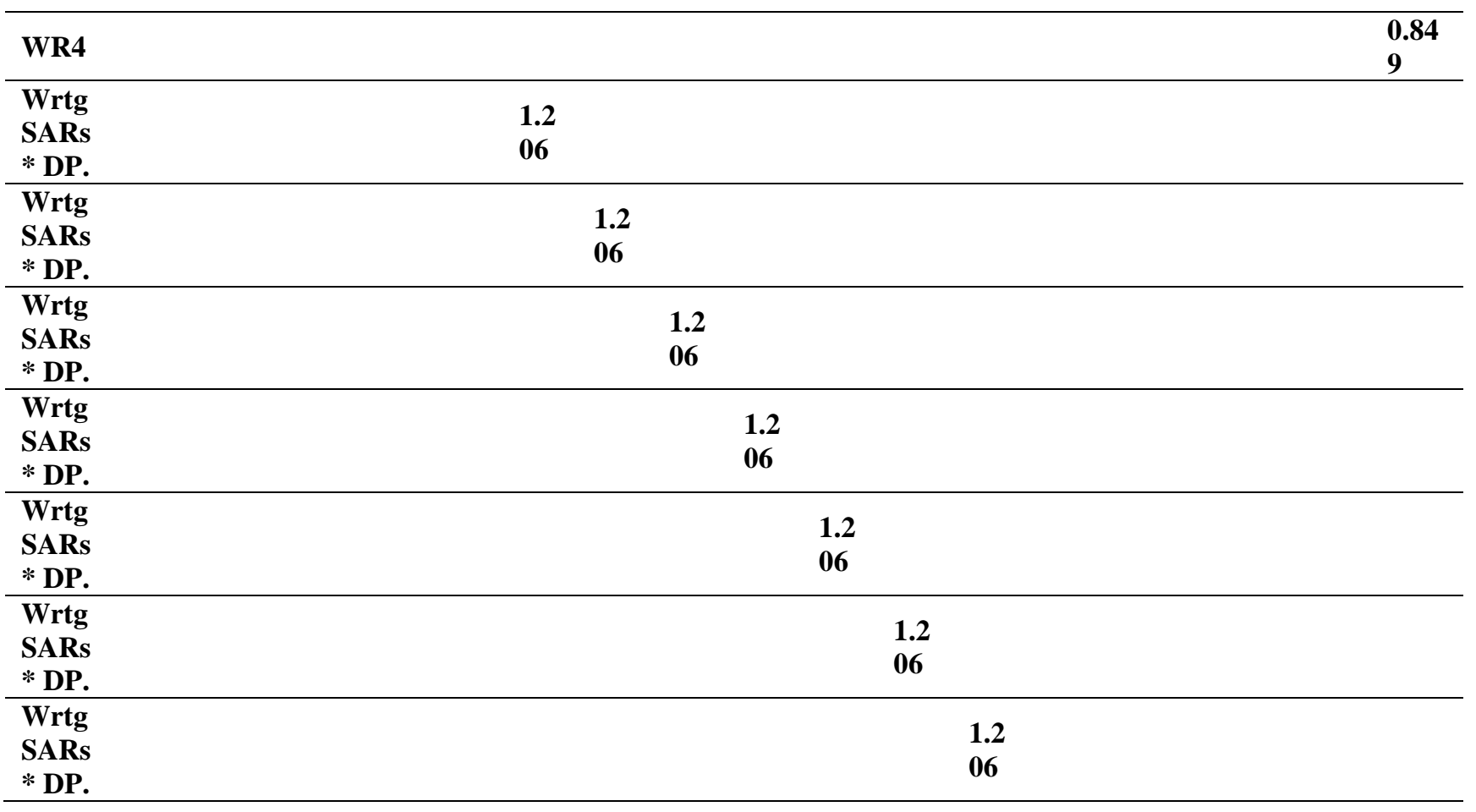

Source: Study Analysis.

Table 5: R-Square (Predictive Accuracy)

\begin{tabular}{lll}
\hline & R Square & R Square Adjusted \\
\hline Curriculum Des. and Cont. Rev. & 0.680 & 0.674 \\
\hline Development of Skills & 0.722 & 0.716 \\
\hline Learning Evaluation & 0.691 & 0.685 \\
\hline Research \& Extension & 0.779 & 0.775 \\
\hline Student Counselling & 0.618 & 0.611 \\
\hline Student Support & 0.763 & 0.758 \\
\hline Teaching-Learning & 0.688 & 0.682 \\
\hline
\end{tabular}

Source: Study Analysis

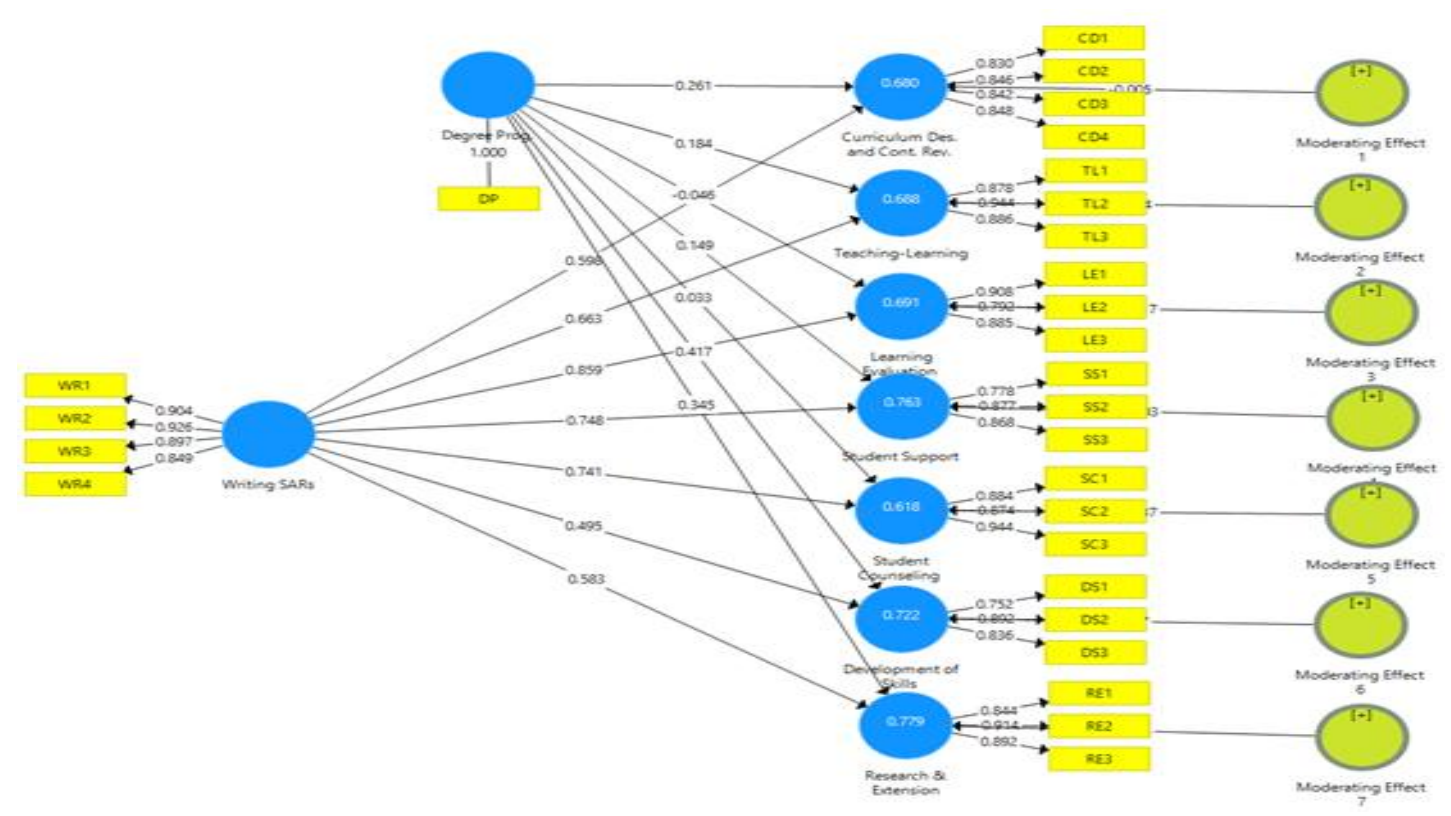

Figure 1: CFA and Outer Loadings

Source: SmartPLS Modelling 
Table 5 reflects the predictive accuracy through R-Square. This is the measure used to highlight the variations caused by the independent variable. Interpretation of the relationship is to provide predictive accuracy in sample space (Benitez et al., 2020) \& is the same as of multiple regression (Andreev, Heart, Moaz \& Pliskin, 2009). Values 0.75 or above are the values for the extensive relationship between IV and DV (Henseler, Ringle \& Sinkovics, 2009; Hair Ringle \& Sarstedt, 2013). Though according to table 2 , the lowest value of R-Square is 0.680 , and two values are above 0.75 i.e., research \& extension and student support. Therefore, these two are termed as extensive relationships and all the other relations are lesser than 0.75 but above than 0.50 and hence termed as moderate fit or relationship.

Similarly, table 6 infers the construct reliability and convergent validity. The table uses Cronbach's alpha; Goldstein rho \& composite reliability to indicate reliability while composite reliability in association with AVE is used to indicate convergent validity (Sijtsma, 2008; Sijtsma, 2009). Although AVE alone is sufficient for highlighting convergent validity although there is a requirement of a minimum 0.5 value for assuring the validity (Ab Hamid, Sami \& Sidek, 2017). Thus, values are sufficient for construct reliability and convergent validity as it demonstrates the values of 0.70 or above from Cronbach's Alpha, Goldstein rho, and composite reliability and 0.50 or above for AVE.

Table 6. Construct Reliability \& Convergent Validity

\begin{tabular}{|c|c|c|c|c|c|c|}
\hline & $\begin{array}{l}\text { Cronbach's } \\
\text { Alpha }\end{array}$ & $\begin{array}{l}\text { rho_ } \\
\text { A }\end{array}$ & $\begin{array}{l}\text { Composite } \\
\text { Reliability }\end{array}$ & $\begin{array}{l}\text { Average } \\
\text { (AVE) }\end{array}$ & Variance & Extracted \\
\hline $\begin{array}{l}\text { Curriculum Des. and } \\
\text { Cont. Rev. }\end{array}$ & 0.863 & 0.872 & 0.907 & 0.708 & & \\
\hline Degree Prog. & 1.000 & 1.000 & 1.000 & 1.000 & & \\
\hline Development of Skills & 0.775 & 0.824 & 0.868 & 0.687 & & \\
\hline Learning Evaluation & 0.829 & 0.848 & 0.897 & 0.745 & & \\
\hline Moderating Effect 1 & 1.000 & 1.000 & 1.000 & 1.000 & & \\
\hline Moderating Effect 2 & 1.000 & 1.000 & 1.000 & 1.000 & & \\
\hline Moderating Effect 3 & 1.000 & 1.000 & 1.000 & 1.000 & & \\
\hline Moderating Effect 4 & 1.000 & 1.000 & 1.000 & 1.000 & & \\
\hline Moderating Effect 5 & 1.000 & 1.000 & 1.000 & 1.000 & & \\
\hline Moderating Effect 6 & 1.000 & 1.000 & 1.000 & 1.000 & & \\
\hline Moderating Effect 7 & 1.000 & 1.000 & 1.000 & 1.000 & & \\
\hline Research \& Extension & 0.860 & 0.866 & 0.915 & 0.781 & & \\
\hline Student Counselling & 0.884 & 0.894 & 0.928 & 0.812 & & \\
\hline Student Support & 0.797 & 0.825 & 0.879 & 0.709 & & \\
\hline Teaching-Learning & 0.886 & 0.894 & 0.930 & 0.815 & & \\
\hline Writing SARs & 0.916 & 0.917 & 0.941 & 0.800 & & \\
\hline
\end{tabular}

Source: Study Analysis

Besides, table 7 below is positing the discriminant validity through the Heterotrait-Monotrait ratio. The purpose of the ratio is to highlight dissimilarity in the variables of the same construct through correlation among variables (Cheung \& Lee, 2010). The maximum value by which two variables of the same construct are allowed to correlate is 0.85 (Hair et al., 2019). Thus, as per the values of the HTMT ratio, there are no variables that are correlating with the other as there is no junction that has a value of 0.85 or above.

Table 7: Discriminant Validity (HTMT)

\begin{tabular}{lllllllllllllllll}
\hline Curriculu & De & Dev & Lea & M & M & M & M & M & M & M & Re & Stu & St & Teac & Wri \\
m Des. & g & of & rn. & od & od & od & od & od & od & od & s & d & d & h.Le & ting \\
and Cont. & Pr & Skil & Eva & Eff & Eff & Eff & Eff & Eff & Eff & Eff & $\begin{array}{l}\text { Ex } \\
\text { Co }\end{array}$ & Su & arni & SA \\
Rev. & og. & ls & l. & 1 & $\mathbf{2}$ & $\mathbf{3}$ & $\mathbf{4}$ & $\mathbf{5}$ & $\mathbf{6}$ & $\mathbf{7}$ & $\begin{array}{l}\text { t } \\
\text { uns }\end{array}$ & pp & ng & Rs \\
\hline
\end{tabular}

\section{Curriculu \\ m Des. \\ and Cont.}

Rev.

\begin{tabular}{lll}
$\begin{array}{l}\text { Degree } \\
\text { Prog. }\end{array}$ & 0.792 & \\
\hline $\begin{array}{l}\text { Dev of } \\
\text { Skills }\end{array}$ & 0.522 & $\begin{array}{l}0.4 \\
12\end{array}$ \\
\hline
\end{tabular}




\begin{tabular}{|c|c|c|c|c|c|c|c|c|c|c|c|c|c|c|c|}
\hline $\begin{array}{l}\text { Learn. } \\
\text { Eval. }\end{array}$ & 0.642 & $\begin{array}{l}0.7 \\
09\end{array}$ & $\begin{array}{l}0.3 \\
11\end{array}$ & & & & & & & & & & & & \\
\hline Mod Eff 1 & 0.310 & $\begin{array}{l}0.3 \\
21\end{array}$ & $\begin{array}{l}0.5 \\
19\end{array}$ & $\begin{array}{l}0.2 \\
91\end{array}$ & & & & & & & & & & & \\
\hline Mod Eff 2 & 0.549 & $\begin{array}{l}0.5 \\
12\end{array}$ & $\begin{array}{l}0.7 \\
81\end{array}$ & $\begin{array}{l}0.6 \\
71 \\
\end{array}$ & $\begin{array}{l}\mathbf{0 . 4} \\
98\end{array}$ & & & & & & & & & & \\
\hline Mod Eff 3 & 0.544 & $\begin{array}{l}0.3 \\
17\end{array}$ & $\begin{array}{l}0.5 \\
10\end{array}$ & $\begin{array}{l}.8 \\
32\end{array}$ & $\begin{array}{l}0.6 \\
11\end{array}$ & $\begin{array}{l}0.3 \\
82\end{array}$ & & & & & & & & & \\
\hline Mod Eff 4 & 0.431 & $\begin{array}{l}0.5 \\
81\end{array}$ & $\begin{array}{l}0.4 \\
91\end{array}$ & $\begin{array}{l}0.6 \\
11 \\
\end{array}$ & $\begin{array}{l}0.4 \\
66\end{array}$ & $\begin{array}{l}0.8 \\
06 \\
\end{array}$ & $\begin{array}{l}0.8 \\
31\end{array}$ & & & & & & & & \\
\hline Mod Eff 5 & 0.589 & $\begin{array}{l}0.6 \\
12\end{array}$ & $\begin{array}{l}0.7 \\
83\end{array}$ & $\begin{array}{l}0.6 \\
17\end{array}$ & $\begin{array}{l}0.5 \\
82\end{array}$ & $\begin{array}{l}0.7 \\
88\end{array}$ & $\begin{array}{l}0.3 \\
89\end{array}$ & $\begin{array}{l}0.7 \\
78\end{array}$ & & & & & & & \\
\hline Mod Eff 6 & 0.311 & $\begin{array}{l}0.3 \\
19\end{array}$ & $\begin{array}{l}0.8 \\
05\end{array}$ & $\begin{array}{l}0.3 \\
19\end{array}$ & $\begin{array}{l}0.7 \\
01\end{array}$ & $\begin{array}{l}0.7 \\
81\end{array}$ & $\begin{array}{l}0.6 \\
08\end{array}$ & $\begin{array}{l}0.5 \\
60\end{array}$ & $\begin{array}{l}0.8 \\
22\end{array}$ & & & & & & \\
\hline Mod Eff 7 & 0.721 & $\begin{array}{l}0.6 \\
91\end{array}$ & $\begin{array}{l}0.3 \\
19\end{array}$ & $\begin{array}{l}0.7 \\
95\end{array}$ & $\begin{array}{l}0.7 \\
62\end{array}$ & $\begin{array}{l}0.8 \\
14 \\
\end{array}$ & $\begin{array}{l}0.7 \\
79\end{array}$ & $\begin{array}{l}0.6 \\
18 \\
\end{array}$ & $\begin{array}{l}0.6 \\
58\end{array}$ & $\begin{array}{l}0.6 \\
98\end{array}$ & & & & & \\
\hline $\begin{array}{ll}\text { Res } & \& \\
\text { Ext } & \end{array}$ & 0.499 & $\begin{array}{l}0.7 \\
11\end{array}$ & $\begin{array}{l}0.6 \\
02\end{array}$ & $\begin{array}{l}0.5 \\
78\end{array}$ & $\begin{array}{l}0.3 \\
81\end{array}$ & $\begin{array}{l}0.6 \\
87\end{array}$ & $\begin{array}{l}0.7 \\
78\end{array}$ & $\begin{array}{l}0.5 \\
82\end{array}$ & $\begin{array}{l}0.4 \\
18\end{array}$ & $\begin{array}{l}0.3 \\
98 \\
\end{array}$ & $\begin{array}{l}0.8 \\
02\end{array}$ & & & & \\
\hline $\begin{array}{l}\text { Student } \\
\text { Counselli } \\
\text { ng }\end{array}$ & 0.712 & $\begin{array}{l}0.6 \\
75\end{array}$ & $\begin{array}{l}0.5 \\
20\end{array}$ & $\begin{array}{l}0.4 \\
99\end{array}$ & $\begin{array}{l}0.3 \\
80\end{array}$ & $\begin{array}{l}0.3 \\
80\end{array}$ & $\begin{array}{l}0.3 \\
80\end{array}$ & $\begin{array}{l}0.3 \\
80\end{array}$ & $\begin{array}{l}0.3 \\
80\end{array}$ & $\begin{array}{l}0.3 \\
80\end{array}$ & $\begin{array}{l}0.3 \\
80\end{array}$ & $\begin{array}{l}0.8 \\
35\end{array}$ & & & \\
\hline $\begin{array}{l}\text { Stud } \\
\text { Supp }\end{array}$ & 0.346 & $\begin{array}{l}\mathbf{0 . 8} \\
23\end{array}$ & $\begin{array}{l}\mathbf{0 . 7} \\
\mathbf{9 0}\end{array}$ & $\begin{array}{l}0.6 \\
15\end{array}$ & $\begin{array}{l}0.3 \\
71\end{array}$ & $\begin{array}{l}0.3 \\
71\end{array}$ & $\begin{array}{l}0.3 \\
71\end{array}$ & $\begin{array}{l}0.3 \\
71\end{array}$ & $\begin{array}{l}0.3 \\
71 \\
\end{array}$ & $\begin{array}{l}0.3 \\
71 \\
\end{array}$ & $\begin{array}{l}0.3 \\
71\end{array}$ & $\begin{array}{l}0.7 \\
98\end{array}$ & $\begin{array}{l}0.4 \\
61\end{array}$ & & \\
\hline $\begin{array}{l}\text { Teach. } \\
\text { Learning }\end{array}$ & 0.821 & $\begin{array}{l}0.7 \\
65\end{array}$ & $\begin{array}{l}0.4 \\
98\end{array}$ & $\begin{array}{l}0.7 \\
73\end{array}$ & $\begin{array}{l}0.3 \\
76\end{array}$ & $\begin{array}{l}0.3 \\
76\end{array}$ & $\begin{array}{l}0.3 \\
76\end{array}$ & $\begin{array}{l}0.3 \\
76\end{array}$ & $\begin{array}{l}0.3 \\
76\end{array}$ & $\begin{array}{l}0.3 \\
76\end{array}$ & $\begin{array}{l}0.3 \\
76\end{array}$ & $\begin{array}{l}0.5 \\
58\end{array}$ & $\begin{array}{l}0.8 \\
29\end{array}$ & $\begin{array}{l}\text { 0. } \\
49 \\
0\end{array}$ & \\
\hline $\begin{array}{l}\text { Writing } \\
\text { SARs }\end{array}$ & 0.597 & $\begin{array}{l}0.8 \\
35\end{array}$ & $\begin{array}{l}0.4 \\
21\end{array}$ & $\begin{array}{l}0.6 \\
98\end{array}$ & $\begin{array}{l}0.3 \\
12\end{array}$ & $\begin{array}{l}0.4 \\
22\end{array}$ & $\begin{array}{l}0.7 \\
27\end{array}$ & $\begin{array}{l}0.4 \\
22\end{array}$ & $\begin{array}{l}0.4 \\
22\end{array}$ & $\begin{array}{l}0.4 \\
22\end{array}$ & $\begin{array}{l}0.4 \\
22\end{array}$ & $\begin{array}{l}0.5 \\
77\end{array}$ & $\begin{array}{l}0.5 \\
72\end{array}$ & $\begin{array}{l}0 . \\
49 \\
8\end{array}$ & $\begin{array}{l}0.78 \\
0\end{array}$ \\
\hline
\end{tabular}

Source: Study Analysis

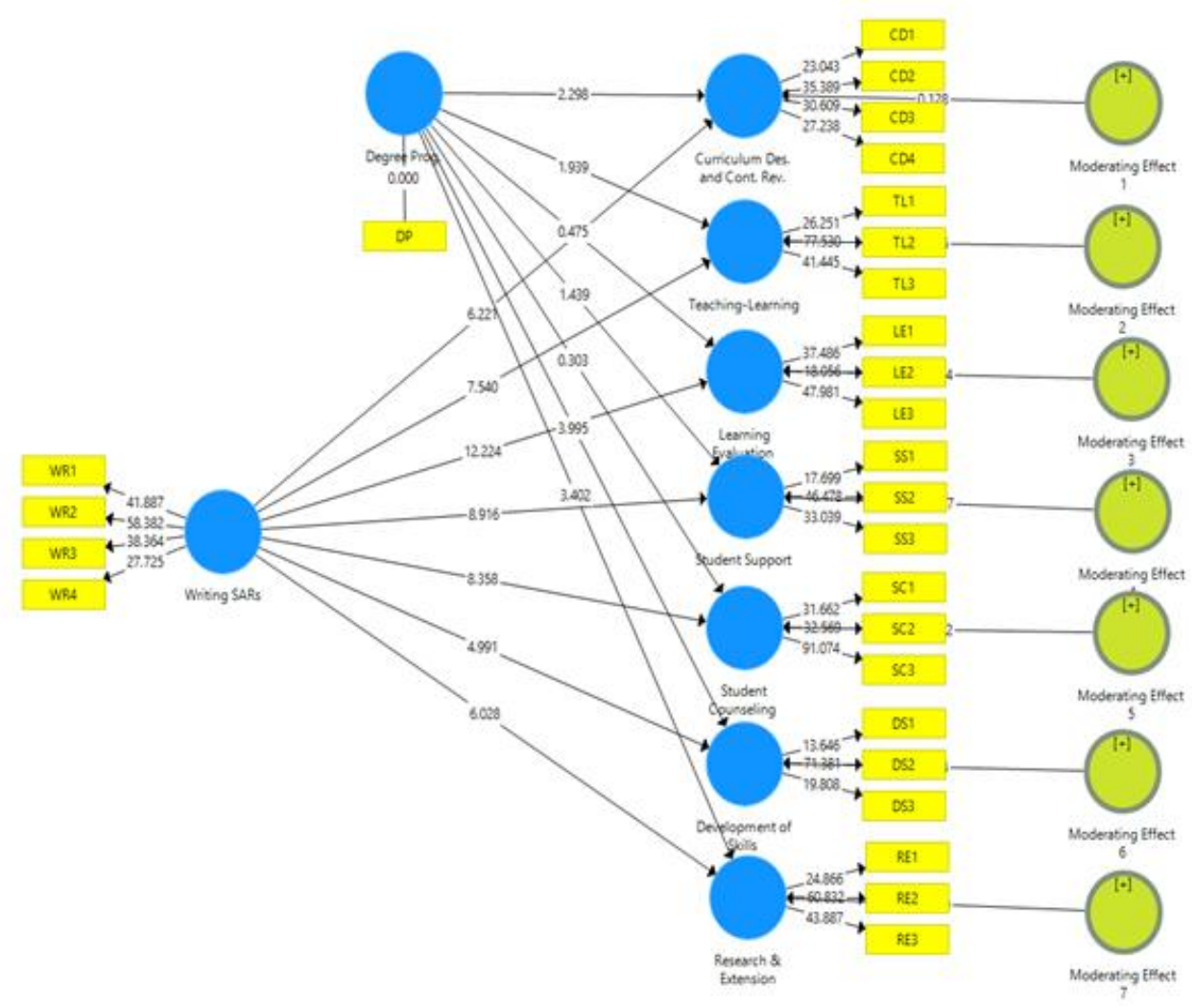

Figure 2: Regression Weights and Path-Coefficients

Source: PLS Path Model 
Table 8: Path Coefficients (Total Effect)

\begin{tabular}{|c|c|c|c|c|c|}
\hline & $\begin{array}{l}\text { Original } \\
\text { Sample }(0)\end{array}$ & $\begin{array}{l}\text { Sample } \\
\text { Mean } \\
\text { (M) }\end{array}$ & $\begin{array}{l}\text { Std.Deviation } \\
\text { (STDEV) }\end{array}$ & $\begin{array}{lr}\text { T } & \text { Statistics } \\
(|\mathrm{O} / \mathrm{STDEV}|)\end{array}$ & $\begin{array}{l}\mathbf{P} \\
\text { Values }\end{array}$ \\
\hline $\begin{array}{l}\text { Degree Prog. -> Curriculum Des. and } \\
\text { Cont. Rev. }\end{array}$ & 0.261 & 0.250 & 0.114 & 2.298 & 0.022 \\
\hline $\begin{array}{lllll}\begin{array}{l}\text { Degree } \\
\text { Skills }\end{array} & \text { Prog. } & \rightarrow & \text { Development } & \text { of } \\
\end{array}$ & 0.417 & 0.403 & 0.104 & 3.995 & 0.000 \\
\hline Degree Prog. -> Learning Evaluation & -0.046 & -0.057 & 0.096 & 0.475 & 0.635 \\
\hline 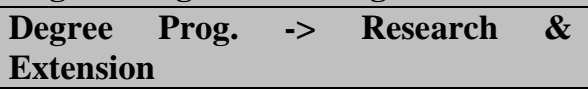 & 0.345 & 0.342 & 0.101 & 3.402 & 0.001 \\
\hline Degree Prog. -> Student Counseling & 0.033 & 0.024 & 0.110 & 0.303 & 0.762 \\
\hline Degree Prog. -> Student Support & 0.149 & 0.137 & 0.103 & 1.439 & 0.151 \\
\hline Degree Prog. -> Teaching-Learning & 0.184 & 0.185 & 0.095 & 1.939 & 0.053 \\
\hline $\begin{array}{l}\text { Moderating Effect } 1 \text {-> Curriculum } \\
\text { Des. and Cont. Rev. }\end{array}$ & -0.005 & -0.009 & 0.037 & 0.128 & 0.898 \\
\hline $\begin{array}{l}\text { Moderating Effect } 2 \text {-> Teaching- } \\
\text { Learning }\end{array}$ & -0.024 & -0.024 & 0.028 & 0.826 & 0.409 \\
\hline 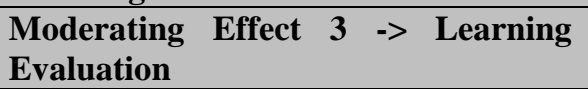 & -0.017 & -0.020 & 0.033 & 0.504 & 0.614 \\
\hline $\begin{array}{lllll}\begin{array}{l}\text { Moderating } \\
\text { Support }\end{array} & \text { Effect } & 4 & \rightarrow & \text { Student } \\
\end{array}$ & -0.003 & -0.005 & 0.033 & 0.087 & 0.931 \\
\hline $\begin{array}{lllll}\begin{array}{l}\text { Moderating } \\
\text { Counseling }\end{array} & \text { Effect } & 5 & \rightarrow & \text { Student } \\
\end{array}$ & -0.037 & -0.038 & 0.041 & 0.902 & 0.368 \\
\hline $\begin{array}{l}\text { Moderating Effect } 6 \text {-> Development } \\
\text { of Skills }\end{array}$ & 0.037 & 0.036 & 0.037 & 0.994 & 0.321 \\
\hline $\begin{array}{l}\text { Moderating Effect } 7 \text {-> Research \& } \\
\text { Extension }\end{array}$ & 0.004 & 0.004 & 0.031 & 0.130 & 0.896 \\
\hline $\begin{array}{l}\text { Writing SARs } \rightarrow \text { Curriculum Des. } \\
\text { and Cont. Rev. }\end{array}$ & 0.598 & 0.607 & 0.096 & 6.221 & 0.000 \\
\hline $\begin{array}{l}\text { Writing SARs } \rightarrow>\text { Development of } \\
\text { Skills }\end{array}$ & 0.495 & 0.507 & 0.099 & 4.991 & 0.000 \\
\hline $\begin{array}{llll}\begin{array}{l}\text { Writing } \\
\text { Evaluation }\end{array} & \text { SARs } & -> & \text { Learning } \\
\end{array}$ & 0.859 & 0.868 & 0.070 & 12.224 & 0.000 \\
\hline $\begin{array}{lllll}\begin{array}{l}\text { Writing } \\
\text { Extension }\end{array} & \text { SARs } & -> & \text { Research } & \& \\
\end{array}$ & 0.583 & 0.587 & 0.097 & 6.028 & 0.000 \\
\hline Writing SARs -> Student Counseling & 0.741 & 0.748 & 0.089 & 8.358 & 0.000 \\
\hline Writing SARs -> Student Support & 0.748 & 0.759 & 0.084 & 8.916 & 0.000 \\
\hline Writing SARs -> Teaching-Learning & 0.663 & 0.658 & 0.088 & 7.540 & 0.000 \\
\hline
\end{tabular}

Source: Study Analysis

The combination of Figure 2 and Table 8 present the inferential section of SmartPLS indicate the perceived significance and advantages of writing SARs. The results depict that the SARs are perceived as beneficial for all the major determinants i.e., Curriculum Design \& Content, Review; Development of Skills, Learning Evaluation, Research \& Extension, Student Counseling, Student Support, and Teaching-Learning. Although degree program is creating effect only on Curriculum Design \& Content, Review; Development of Skills, Learning Evaluation, Research \& Extension. Thus, moderation of degree program with the significance and benefits of SARs writing result in nullifying the effect as moderation has resulted in the acceptance of null hypotheses.

\section{CONCLUSION}

The findings of the study are linked and also are found consistent with Islam and Chowdhury (2015) that all the elements found critical in Bangladesh are also termed important in the scenario of Pakistan. Although in Pakistan, SARs are used for the evaluation of programs rather than the entire discipline and hence the moderation of different degree programs indicated that variables are not found consistent. Therefore, it is justifiable to consider the criterion raised by Raouf (2006) that every program has different significance for students and faculty and therefore needs to be evaluated separately.

A similar sort of indication was made initially by Khatoon and Usmani (2014), although the criterion they evaluated is 
not concerning the significance of SARs. Therefore, this study proposes a systematic framework to relate SAR writing with the perceived benefits rather than methods to write SARs.

\section{AREA FOR FUTURE RESEARCH}

This study has only covered the reference of faculties of those universities which are ranked in the category of business education by HEC in Pakistan. Although other universities and HEIs in the general category are also providing business education, hence, a clearer picture might be created by including all universities and HEIs in the sample. Similarly, if the study may compare the benefits of SAR writing for business education and general sector or private or public sector then a more effective and clear depiction will be produced.

\section{ACKNOWLEDGEMENT}

This study was funded by Coral Research and Education Systems Ltd, Pakistan. The authors acknowledge and appreciate the financial support provided by the organization to conduct this research.

\section{AUTHOR'S CONTRIBUTION}

Sadia Shaikh has contributed to the overall research writeup and assisted in data analyses of this study. She has also corresponded with the journal for the entire publication process.

Mushtaque Ali Jariko provided with his expert guidance on the subject and research framework. He has also majorly contributed to the literature review write-up.

Muhammad Faisal Sultan has contributed to data analysis and research writeup in this research project.

Asif Qureshi conducted the literature review and data analysis.

Tania Memon Mushtaq helped refine the manuscript with APA formatting of the text, citations, and references.

All authors equally contributed to data collection for this research study.

\section{REFERENCES}

1. Ab Hamid, M. R., Sami, W., \& Mohmad Sidek, M. H. (2017). Discriminant Validity Assessment: Use of Fornell \& Larcker criterion versus HTMT Criterion. Journal of Physics: Conference Series, 890, 012163. https://doi.org/10.1088/1742-6596/890/1/012163

2. Afthanorhan, W. M. A. B. W. (2014). Hierarchical component using reflective-formative measurement model in partial least square structural equation modelling (Pls-Sem). International Journal of Mathematics, 2(2), 3349.

3. Aliyu, A., Maglaras, L., He, Y., Yevseyeva, I., Boiten, E., Cook, A., \& Janicke, H. (2020). A Holistic Cybersecurity Maturity Assessment Framework for Higher Education Institutions in the United Kingdom. Applied Sciences, 10(10), 3660. https://doi.org/10.3390/app10103660

4. Andrade, H., \& Valtcheva, A. (2009). Promoting Learning and Achievement Through Self-Assessment. Theory into Practice, 48(1), 12-19. https://doi.org/10.1080/00405840802577544

5. Andreev, P., Heart, T., Maoz, H., \& Pliskin, N. (2009). Validating formative partial least squares (PLS) models: methodological review and empirical illustration. ICIS 2009 proceedings, 193.

6. Batool, Z., \& Qureshi, R. H. (2017). Quality assurance manual for higher education in Pakistan. Higher Education Commission, Pakistan.

7. Bawden, D. (2007). Complex Knowledge: Studies in Organizational Epistemology20073Haridimos Tsoukas. Complex Knowledge: Studies in Organizational Epistemology. Oxford: Oxford University Press 2005. xii + 414 pp., ISBN: 0-19-927557-2. Journal of Documentation, 63(4), 594-595. https://doi.org/10.1108/00 220410710759048

8. Becket, N., \& Brookes, M. (2008). Quality management practice in higher education-What quality are we actually enhancing? Journal of Hospitality, Leisure, Sports and Tourism Education (Pre-2012), 7(1), 40. https://doi.org/10.3794/johlste.71.174

9. Benitez, J., Henseler, J., Castillo, A., \& Schuberth, F. (2020). How to perform and report an impactful analysis using partial least squares: Guidelines for confirmatory and explanatory IS research. Information \& Management, 57(2), 103 - 168. https://doi.org/10.1016/j.im.2019.05.003

10. Boud, D., \& Falchikov, N. (1989). Quantitative studies of student self-assessment in higher education: A critical analysis of findings. Higher education, 18(5), 529-549. https://doi.org/10.1007/BF00138746

11. Boud, D., \& Falchikov, N. (2006). Aligning assessment with long-term learning. Assessment \& evaluation in higher education, 31(4), 399-413. https://doi.org/10.1080/02602930600679050

12. Budiyanti, H., Patiro, S. P. S., Djajadi, M., \& Astuty, S. (2020). Does Service Quality in Education and Training Process Matters? Study of Government's Human Resource Agencies in Indonesia. Journal on Efficiency and Responsibility in Education and Science, 13(1), 41-55. https://doi.org/10.7160/erie sj.2020.130104 
13. Cheung, C. M., \& Lee, M. K. (2010). A theoretical model of intentional social action in online social networks. Decision Support Systems, 49(1), 24-30. https://doi.org/10.1016/j.dss.2009.12.006

14. Dunning, D., Heath, C., \& Suls, J. M. (2004). Flawed self-assessment: Implications for health, education, and the workplace. Psychological science in the public interest, 5(3), 69-106. https://doi.org/10.1111/j.15291006.2004.00018.x

15. Evans, C. (2013). Making sense of assessment feedback in higher education. Review of educational research, 83(1), 70-120. https://doi.org/10.3102/0034654312474350

16. Fornell, C., \& Larcker, D. F. (1981). Structural Equation Models with Unobservable Variables and Measurement Error: Algebra and Statistics. Journal of Marketing Research, 18(3), 382-388. https://doi.org/10.1177/002224378101800313

17. Forsman, H., Jansson, I., Leksell, J., Lepp, M., Sundin Andersson, C., Engström, M., \& Nilsson, J. (2020). Clusters of competence: Relationship between self-reported professional competence and achievement on a national examination among graduating nursing students. Journal of advanced nursing, 76(1), 199-208. https://doi.org/10.1111/JAN.14222/v2/response1

18. Habib, M. N., Jamal, W., Khalil, U., \& Khan, Z. (2020). Transforming universities in the interactive digital platform: case of city university of science and information technology. Education and Information Technologies, 1-25. https://doi.org/10.1007/s10639-020-10237-w

19. Habib, M. N., Khalil, U., Khan, Z., \& Zahid, M. (2021). Sustainability in higher education: what is happening in Pakistan? International Journal of Sustainability in Higher Education. https://doi.org/10.1108/IJSHE-062020-0207

20. Hair, J. F., Ringle, C. M., \& Sarstedt, M. (2013). Partial Least Squares Structural Equation Modeling: Rigorous Applications, Better Results and Higher Acceptance. Long Range Planning, 46(1-2), 1-12. https://doi.org/10.1016/j.lrp.2013.01.001

21. Hair, J. F., Risher, J. J., Sarstedt, M., \& Ringle, C. M. (2019). When to use and how to report the results of PLS-SEM. European Business Review, 31(1), 2-24. https://doi.org/10.1108/EBR-11-2018-0203

22. Hair, J. F., Sarstedt, M., Ringle, C. M., \& Mena, J. A. (2011). An assessment of the use of partial least squares structural equation modelling in marketing research. Journal of the Academy of Marketing Science, 40(3), 414433. https://doi.org/10.1007/s11747-011-0261-6

23. Hartley, J., \& Downe, J. (2007). The Shining Lights? Public Service Awards as an Approach to Service Improvement. Public Administration, 85(2), 329-353. https://doi.org/10.1111/j.1467-9299.2007.00652.x

24. Henseler, J., Ringle, C. M., \& Sinkovics, R. R. (2009). The use of partial least squares path modelling in international marketing. Advances in International Marketing, 277-319. https://doi.org/10.1108/S14747979(2009)0000020014

25. Higher Education Commission. a (n.d.). Quality Enhancement Cells in HEIs. HEC, Pakistan. Retrieved February 14, 2021, from https://www.hec.gov.pk/english/services/universities/QAA/Pages/QECs.aspx

26. Higher Education Commission. b (n.d.). HEC recognized campuses. HEC, Pakistan. Retrieved February 15 , 2021, from https://www.hec.gov.pk/english/universities/Pages/DAIs/HEC-recognized-Campuses.aspx

27. Islam, M. N., \& Chowdhury, M. A. F. (2015). Self-assessment in higher education: empirical evidence from the Department of Business Administration of Shahjalal University of Science and Technology, Bangladesh. International Journal of Innovation in Education,3(1), 62-88. https://doi.org/10.1504/IJ IIE.2015.074705

28. Johns, R. (2005). One Size Doesn't Fit All: Selecting Response Scales for Attitude Items. Journal of Elections, Public Opinion \& Parties, 15(2), 237-264. https://doi.org/10.1080/13689880500178849

29. Johns, R. (2010). Likert items and scales. Survey question bank: Methods fact sheet, 1(1), 11.

30. José Tarí, J. (2010). Self-assessment processes: the importance of follow-up for success. Quality Assurance in Education, 18(1), 19-33. https://doi.org/10.1108/09684881011015972

31. Khan, A. M., \& Ramzan, A. (2020). Conceptual Content Analysis: Policy Documentation for the Quality of Higher Education in Pakistan. Pakistan Journal of Education, 37(1). https://doi.org/10.30971/pje.v37i1.1131

32. Khan, G. F., Sarstedt, M., Shiau, W. L., Hair, J. F., Ringle, C. M., \& Fritze, M. P. (2019). Methodological research on partial least squares structural equation modelling (PLS-SEM). Internet Research, 29(3), 407-429. https://doi.org/10.1108/IntR-12-2017-0509

33. Khatoon, S., \& Usmani, M. A. W. (2014). Effectiveness of program evaluation through the HEC prescribed self-assessment model in improving the quality of degree programs in a public sector university in Pakistan. International Journal of Physical and Social Sciences, 4(1), 42-72.

34. Likert, R. (1932). A technique for the measurement of attitudes. Archives of Psychology, 22 (140), 5.

35. McAdam, R., \& Welsh, W. (2000). A critical review of the business excellence quality model applied to further education colleges. Quality Assurance in Education, 8(3), 120-130. https://doi.org/10.1108/0968 $\underline{4880010372716}$

36. Monteiro, P., \& Nicolini, D. (2014). Recovering Materiality in Institutional Work. Journal of Management Inquiry, 24(1), 61-81. https://doi.org/10.1177/1056492614546221

37. Paris, S. G., \& Paris, A. H. (2001). Classroom Applications of Research on Self-Regulated Learning. Educational Psychologist, 36(2), 89-101. https://doi.org/10.1207/S15326985EP3602_4 
38. Pratama, A. B. (2019). The landscape of public service innovation in Indonesia. Innovation \& Management Review, 17(1), 25-40. https://doi.org/10.1108/INMR-11-2018-0080

39. Rahnuma, N. (2020). Evolution of quality culture in an HEI: critical insights from university staff in Bangladesh. Educational Assessment, Evaluation and Accountability, 32(1), 53-81. https://doi.org/10.1007/s 11092-019-09313-8

40. Raouf, A. (2006). Self-assessment manual. UMT, Lahore.

41. Revilla, M. A., Saris, W. E., \& Krosnick, J. A. (2013). Choosing the Number of Categories in Agree-Disagree Scales. Sociological Methods \& Research, 43(1), 73-97. https://doi.org/10.1177/0049124113509605

42. Richter, N. F., Sinkovics, R. R., Ringle, C. M., \& Schlägel, C. (2016). A critical look at the use of SEM in international business research. International Marketing Review, 33(3), 376-404. https://doi.org/10.1108/IMR$\underline{04-2014-0148}$

43. Sarstedt, M., Ringle, C. M., \& Hair, J. F. (2017). Partial Least Squares Structural Equation Modeling. Handbook of Market Research, 1-40. https://doi.org/10.1007/978-3-319-05542-8_15-1

44. Schunk, D. H., \& Ertmer, P. A. (1999). Self-regulatory processes during computer skill acquisition: Goal and self-evaluative influences. Journal of Educational Psychology, 91(2), 251-260. https://doi.org/10.1037/00220663.91 .2 .251

45. Sijtsma, K. (2008). Reliability Beyond Theory and Into Practice. Psychometrika, 74(1), 169-173. https://doi.org/10.1007/s11336-008-9103-y

46. Sijtsma, K. (2009). Correcting Fallacies in Validity, Reliability, and Classification. International Journal of Testing, 9(3), 167-194. https://doi.org/10.1080/15305050903106883

47. Sitzmann, T., Ely, K., Brown, K. G., \& Bauer, K. N. (2010). Self-Assessment of Knowledge: A Cognitive Learning or Affective Measure? Academy of Management Learning \& Education, 9(2), $169-191$. https://doi.org/10.5465/amle.9.2.zqr169

48. Stuart, M. R., Goldstein, H. S., \& Snope, F. C. (1980). Self-evaluation by residents in family medicine. The Journal of family practice, 10(4), 639-642.

49. Sultan, M. F., Shaikh, S., Khaskelly, F. Z., \& Khalid, S. (2019). Factors Affecting Female Career Advancement: Comparative Study of Higher Education Sector, Banking Production and Construction Sectors of Karachi. The Women-Annual Research Journal of Gender Studies, 11(11).

50. Turi, J. A., Javed, Y., Bashir, S., Khaskhelly, F. Z., Shaikh, S., \& Toheed, H. (2019). Impact of Organizational Learning Factors on Organizational Learning Effectiveness through Mobile Technology. Quality-Access to Success, 20(171).

51. Uddin, M. K. (2016). A Draft Report on Assessment of Quality of Education in the Department of Psychology, University of Dhaka, Bangladesh. Higher Education, 1, 2.

52. Usmani, M. A., \& Khatoon, S. (2018). Impact of programme evaluation through self-assessment in higher education institutions in Pakistan. Contemporary Educational Researches Journal, 8(4), 134-141. https://doi.org/10.18844/cerj.v8i3.3638

53. Vykydal, D., Folta, M., \& Nenadál, J. (2020). A Study of Quality Assessment in Higher Education within the Context of Sustainable Development: A Case Study from the Czech Republic. Sustainability, 12(11), 4769. https://doi.org/10.3390/su12114769 